\title{
Songwriting and Human Shadow: Heuristic Inquiry Grounded in Art
}

\author{
Haley Fox ${ }^{1 *}$ \\ 1 Art Therapy department, Adler University, United States \\ *hfox2@adler.edu \\ Received: 27 March 2017 ; Accepted: 12 April 2018 ; Published: 1 July 2018 \\ Editor: Avi Gilboa Reviewers: Dorothea Pienaar, Simon Gilbertson
}

\begin{abstract}
This paper summarizes research first presented in an unpublished dissertation by the author (2005). A rigorous art-based, heuristic methodology in the tradition of Clark Moustakas (1990) examines the author's own experiences with songwriting, spanning over 25 years. Compelling images reveal themselves in the inquiry in songs, dreams, painting, and sculpture as harbingers of human shadow, with undeniable auto-ethnographic features. A model for conceptualizing songwriting in particular and the creative process in general as vehicles for psychological understanding and healing is explored and described for art therapy and music therapy practitioners. The theoretical grounding emerging from this study pays homage to Hillman's work (1977), highlighting an image's autonomy, intent, and a sense of "otherness" owing to emergence from an imaginal realm (versus consensual reality). Images in this context are understood as not only visual but apparent in and able to be rendered through a variety of art modalities. The text highlights (and hyperlinks) a progression of original songs produced in the study, songs that parallel the academic learning and culminate in a final, musical "creative synthesis." A complete song list, an index of images, and references are included.
\end{abstract}

Keywords: arts-based research, art-based research, heuristic, music therapy, art therapy, songwriting, human shadow, auto-ethnography

\section{Introduction}

Many practitioners feel instinctively that art offers a superb avenue to deepen our understanding of the human experience in ways that can make us better therapists. McNiff (1998) made an eloquent case for this in Art-Based Research. His entre into this area has since been advanced in works by Kapitan (2017) and Leavy (2018). What has only recently begun to emerge in the literature are clearly stated epistemologies, procedures, and examples that can offer practical guidance to practitioner-scholars ready to take on an art-based research project. Even Barone and Eisner (2012), who present several examples in their volume Arts-Based Research, relied most heavily on literary and theatrical forms of art and failed to offer any examples grounded in two readily available (albeit less language-based) art forms, visual art and music.

The privilege of being involved in art-based research has produced deep personal insights as well as a thesis, dissertation, and several unpublished writings by this writer. It has also increased clarity in a theoretical orientation grounded solidly in art itself 
and in a method that offers a path to better understanding personal experience and, in a broader sense, the human experience.

"Songwriting and self discovery: A heuristic study grounded in the arts and supported by the theories of Carl Jung and James Hillman" (Fox, 2005) included phenomenological interviews with both novice and professional songwriters while also remaining true to a heuristic methodology in the tradition of Clark Moustakas. The heuristic part of the research involved an intensive self-study of the author's own experiences with songwriting. The text that follows focuses primarily on excerpts from that heuristic, art-based exploration and guides the reader through a landscape of emerging original songs and art to a final creative synthesis, then circles back to examine an emerging conceptual model for psychotherapy grounded in art in the discussion section of the paper.

\section{Theoretical Grounding and Assumptions}

In 1990, Clark Moustakas articulated a method for engaging qualitative, heuristic research to explore human experience. He drew his data for his own study of the lived experience of clinical depression from reading, journaling, and reflection upon his own experience (Moustakas, 1990).

In a separate vein of inquiry, the writings of James Hillman (a neo-Jungian) opened our eyes to the rich wisdom available to Psyche when the time is taken to examine dream images and images that emerge in therapeutic conversations and story. Hillman's (1977) work can easily be extrapolated to understanding images grounded in art, including images emerging from music. All images hail from the Imaginal Realm, after all.

Heuristic inquiry grounded in art (the research niche applied here) has roots in the heuristic method developed by Clark Moustakas (1990) and also in James Hillman's provocative writing $(1977,, 1983,, 1989)$. This approach may not be for everyone and represents only a slice of the vast universe of possibilities for applying artistic lenses and tools to research. That said, let us be clear about assumptions made in the particular approach presented here:

- Art functions as a primary mode of inquiry (denoting art-based research).

- The researcher pays particular attention to mindful examination of and reflection upon her own songwriting and art-making (the heuristic component, per Moustakas, 1990).

- The implementation of the research utilizes characteristically art-based techniques, such as imaginative variation (Moustakas, 1990) and intermodal transfer (Knill et al., 1995, /2005)—-the latter denoting movement among different art forms and renderings to allow images fuller expression; in other words, to deepen one's understanding of each image as it reveals itself in different media.

- Other important tools or attitudes for understanding therapeutic material, including that generated by art-making, include phenomenological reduction (appreciating the thing itself separate from any external theory or comparison) and also Epoché, a discipline in which a researcher practices standing apart from the views of others; e.g., with regard to interview content (or apart from images, as they reveal themselves), while remaining cognizant of one's own biases. The concept of Epoché is elucidated well in Moustakas (1994).

A comparison of heuristic inquiry grounded in art with other more traditional forms of research appears in the table 1 . Note that research grounded in art makes very different assumptions and serves different purposes than either quantitative or qualitative research methods. For example, the method assumes bias not only within human subjects or the experimenter, but also within the images themselves. Data itself is revealed through images rather than being collected and measured (quantitative) or communicated through interviews with people (qualitative). And rather than using empirical/ 
Table 1

Comparison of research methodologies (Copyright H. Fox 2018)

\begin{tabular}{|l|l|l|}
\hline \multicolumn{1}{|c|}{ Quantitative Research } & \multicolumn{1}{|c|}{ Qualitative Research } & \multicolumn{1}{|c|}{ Research Grounded in Art } \\
\hline $\begin{array}{l}\text { Equipped to verify or disprove a hypothe- } \\
\text { sis. }\end{array}$ & $\begin{array}{l}\text { Equipped to examine and describe hu- } \\
\text { man experience. }\end{array}$ & $\begin{array}{l}\text { Equipped to explore and discover phe- } \\
\text { nomena. }\end{array}$ \\
\hline Values stability, prediction. & Values understanding. & Values multiplicity, richness. \\
\hline Assumes objectivity, stability & Assumes human bias. & $\begin{array}{l}\text { Assumes all bias, including that which is } \\
\text { grounded in art. }\end{array}$ \\
\hline "Reality" = precisely what is observed. & $\begin{array}{l}\text { Phenomena are altered and impacted by } \\
\text { perceptions. }\end{array}$ & $\begin{array}{l}\text { Each phenomenon reveals itself. (The } \\
\text { "Third.") }\end{array}$ \\
\hline Suited to simple, fixed phenomena. & $\begin{array}{l}\text { Suited to complex, dynamic human phe- } \\
\text { nomena. }\end{array}$ & Suited to complex, dynamic phenomena. \\
\hline Data is collected thru measuring. & $\begin{array}{l}\text { Data is communicated thru interviews } \\
\text { with people. }\end{array}$ & Data is revealed through images. \\
\hline $\begin{array}{l}\text { Data is analyzed thru numerical compar- } \\
\text { isons and statistical inferences. }\end{array}$ & $\begin{array}{l}\text { Intellect is applied to data, comparisons } \\
\text { and common themes noted. }\end{array}$ & $\begin{array}{l}\text { Data synthesizes itself in a creative } \\
\text { process driven by art; Ego is a creative } \\
\text { collaborator. }\end{array}$ \\
\hline $\begin{array}{l}\text { Uses empirical, mathematical interpreta- } \\
\text { tion and judgment. }\end{array}$ & $\begin{array}{l}\text { Uses subjective interpretation and judg- } \\
\text { ment, from the researcher's perspective. }\end{array}$ & $\begin{array}{l}\text { Uses aesthetic interpretation and judg- } \\
\text { ment. }\end{array}$ \\
\hline
\end{tabular}

mathematical (quantitative) or subjective (qualitative) interpretation and judgment, it relies upon aesthetic judgment.

Perhaps the most important discipline required in heuristic inquiry grounded in art, which may not be important in other forms of art-based research, concerns a determination to hold sacred and to value the phenomenon of the Third, the Other, the veritable intentions and teaching that derive not from me as a researcher nor from my human co-researchers in any direct or imagined way but rather from the art itself. In this form of research, art-even art that appears intensely "personal"-leads and guides the research and teaches things previously unknown, things one may never have thought to hypothesize. Indeed, it is counterintuitive here for an artist to "harness" the art, "hold the reigns," or contrive art "directives"; better that the art-based researcher don the proverbial harness and entrust those reigns to the art, to let the art direct the artist. In such a dynamic collaboration, the artist in a real sense takes a back seat while the learning unfolds-often inspiring unexpected surprises, as art is wont to do.

This method of "letting the art lead" can be difficult to grasp, but I have found in my teaching that artists themselves are uniquely equipped for the task, as it mirrors a manner in which we naturally engage with artistic modalities. How do the various members of a jazz ensemble know what note to play next in an improvisation? And how do they know how to play the note in terms of musical dynamics? The players literally follow the music. They serve the music, listen attentively and offer what it needs. (Perhaps a more delicate percussive accompaniment—or a little more cowbell.) How does a painter know when a painting is finished? Does the painter just decide? Not exactly; in a real sense, the painting "tells" the painter when it is finished. The dancer immerses herself in the music that surrounds her and lets it lift her body where the dance needs it to go. The sculptor curiously and carefully chips away at a block of wood until the image wanting to be revealed reveals itself. This all requires a respectful vigilance, a willingness to honor each image's autonomy. Ego can poison the whole process if you let him. Ego must be a respectful and fearless collaborator, willing to receive and 
actively assist in the rendering of images as they reveal themselves. A keen sensitivity is required on the part of the artist, as well as a willingness to let go.

The art-based researcher desiring to adopt and improve the discipline of letting the art lead may find useful the following guidelines (some of which are further elaborated upon in the discussion at the article's end:

1. Stay with the image. Keep going back to the images that emerge, paying particular attention to those images that demand that attention most insistently.

2. Practice the ethical principles of maleficence and beneficence; that is, commit to do no harm to images and indeed to actively promote their best interests.

3. Allow images autonomy in the same way that a person-centered counselor endeavors to allow each client a sense of autonomy. You may need to first work at personifying those images. Have conversations with them. Ask questions. Engage in dialogue as in Carl Jung's tradition of active imagination.

4. When feeling unsure of oneself on how to proceed, proceed as an artist would. To that end, submit to the art and refrain from imposing Ego-based intentions. The latter can be discerned by looking for a sense of otherness that characteristically accompanies images emerging of their own accord.

The existing art-based research literature, still spare but growing, seems to suggest that the primary value of artistic modes of inquiry has to do with the arts offering unique tools a researcher may use to enlighten others. Eisner and Barone (2012) in particular have pointed to the distinct nature of art, emphasizing that the underlying purpose of arts-based research, as they term it, may not be to answer questions but rather to inspire people or even to elicit new questions. I agree that art can do this, and it is a compelling way to proceed in research endeavors, no doubt as legitimate as other more commonly used modes of inquiry.

However, I would argue that art certainly can and does answer questions, when invited, and it answers them particularly well when the inquiry concerns human experience. Answers are seldom simple and straightforward, of course; art is best-suited to noting nuances and elucidating complexities in human nature. I am reminded of a play I saw two years ago, "Carroll Gardens" (Williams, 2016), which masterfully elicited a heightened appreciation for the complexity of the human experience of racism, from several different and sometimes unexpected angles, rather than presenting a simple, reductionist "right" answer to the "problem."

It is important to note that the songs featured and hyperlinked in this text have characteristically emerged "unbidden" to the author-always of their own accord, seeming to possess an intent all their own and often arriving at inopportune moments (for example, while driving or in the middle of the night). Indeed, visual images seemed to emerge in the same way throughout the study, and the sense of "otherness" they characteristically possess contributes to the author's growing understanding of the autonomous images (ushered forth primarily through music, drawings, dreams, and experiences) as harbingers of human shadow.

\section{Songwriting Background of the Researcher}

This writer, the primary subject of the heuristic study, came into the world with an active imagination and a strong sense of musicality, though no professional musicians existed in the family history. I took up the flute in the fourth grade and began piano lessons in my teens, when the family acquired a piano. Despite my mediocrity as a pianist, songs (accompanied by piano) began to come to me-mostly as expressions of adolescent angst-and I acquired the habit of sneaking off to commit them to memory-and even to notate them, though the latter process was slow and laborious.

In college, I bought my first guitar and learned some basic chords. I wrote my first song with guitar accompaniment, When I Was a Child, and a prolific period of clandestine songwriting ensued-concurrent with a budding romance. 
Feeling shy about the songs, I rarely shared them. And when that first romance ended badly, I felt I could not bear to share them at all anymore. They still came to me, infrequently, until about 25 years later, when I entered a doctoral program, and an intense period of self-reflection spurred an even more prolific songwriting era.

I never set out to be a songwriter; indeed, never once have I sat down to "try" to write a song. The songs have always arrived of their own accord, and though I have sometimes found them disturbing, I nevertheless always attempted to honor them, at least enough to find a way to their expression and to jot down the lyrics and simple chords.

\section{Methodology}

Desiring to better understand this songwriting process, I took it on in my doctoral research. The original research question posed in the art-based heuristic inquiry (Fox, 2005) was simply: "What is the experience of songwriting?" The full study included, as noted above, phenomenological interviews with other novice and professional songwriters. The interviews revealed a variety of techniques and strategies, and even formulas, applied by songwriters to usher forth new music. Yet, each of the individual songwriters I interviewed also spoke about a mystery to songwriting, each sharing at least one or two examples of songs arriving "unbidden" from a "Giver of Song" who went by different names: God, the Universe, spirit, human experience, and so on. Most conceded their own "best" songs arrived in this mysterious fashion. The songwriters would insist, for example, "I did not really write that song; in a way, it wrote me."

The following text, as noted, will only present excerpts from the heuristic portion of the study engaged, in which I examined personal experiences with songwriting, in the manner just described, and made space for the appearance of a series of original songs, culminating in a final creative synthesis. (As noted, songs are hyperlinked throughout the text, and a complete song list appears at the end of the text.)

The heuristic exploration was guided by Moustakas' (1990) six stages of heuristic inquiry: initial engagement, immersion, incubation, illumination, explication, and, lastly, creative synthesis. Briefly, I first set the intention (the research question), and from this initial engagement began to immerse myself in a study of the content area through reading and interviews while also adopting a preparedness for receiving songs as they might arrive-for example, bringing my guitar, art and writing material wherever I traveled. I attended to the ways in which song content incubated, began to recognize more consciously the "felt sense" (Gendlin, 1982) that frequently preceded the emergence of a song (a kind of restless, tacit knowing, not yet explicit). I routinely immersed myself in other art-making modalities as well, using intermodal transfer (Knill et al., 1995, /2005) and imaginative variation (Moustakas, 1990) for the purpose of deepening my understanding of compelling images.

Illumination came into play as I noted common themes when examining qualitative research data, including interview data (applying Atlas-ti software for this purpose), and specific explications occurred through the emergence of new songs, artwork, and written notes that in time began to make sense of the material, particularly through the lens of an understanding of human shadow.

A brief definition of human shadow may be in order here. Jungian scholar MarieLouise von Franz (1995) once quoted Jung as saying in a personal conversation with her that he understood human shadow to be "the whole of the unconscious" (p. 3). Put another way, human shadow is essentially anything a human cannot bear to look at, and therefore we tend to repress it or project it onto others. By not owning our own shadow material, we deprive ourselves of wholeness and can also enable strong and even violent feelings towards others who hold our projections.

Finally, a creative synthesis emerged after nearly four years of study, apparent in the written dissertation itself but more particularly in a single song that (to the writer's surprise) musically synthesized components of many others that had preceded. That song was Be Careful What You Wish For. 


\section{The Song Series and Creative Synthesis}

It didn't take long to realize that songs were powerful harbingers of human shadow and had been revealing human shadow material to me for years; however, their language was cryptic and mysterious, and they did not compel particular academic attention until The Well arrived one evening in February 2001. An excerpt from my personal journal:

I was attending a graduate seminar with Beverly Rubik entitled "Science and Consciousness," burying myself in the content and enjoying it immensely. One evening, I sat alone on my bed, when The Well began to erupt from within me and compelled me to seize my guitar. This song struck me as something terribly different from the lyrical, flowing ballads I tended towards until that point in time. First of all, I was stunned by this song's intensity and urgency. It came out in a feverish gush and left me shaking for several minutes afterwards. Unlike the songs that had preceded it, this one included spoken lines, cursing, humor and puzzling images. Although time seemed suspended when the song erupted, I know that I wrote it in about the time it took to sing it-around three minutes. The lyrics follow:

\section{The Well}

I discovered a well today. It had a deep, deep crack.

The damned thing was leaking; that's what gave it away.

I want my money back. ${ }^{1}$

What the Hell's in it then? It's filled with sadness and pain.

Are you sure that's all? Well, let me look again.

I discovered a well today. It had a deep, deep crack.

Stuff spillin' out of it all over the place. And I can't put it back.

It opened prematurely. It's twenty-five years late.

Go on, take another look. No, no, no - please let me wait.

We both know it's too late.

I discovered a well today. It's got a deep, deep crack.

The Well heralded a particularly prolific period of songwriting. It got my attention. I decided to explore the image of the Well more deeply and brought it to an art-based research group I formed, comprised of myself and four other female artists: a sculptor, a painter/pianist, a potter, and a painter/graphic artist. At our first session, we worked with clay, and I chose to explore the image of the Well, which was at that point more a feeling-sense than a visual idea. The result of this first attempt at elaborating upon the image can be seen in Figure 1, below.

When we gathered around to view our art pieces, everyone seemed to have a strong response to mine. Half the group (including me) felt drawn to it and enthusiastic about it, while the others felt disturbed and repulsed. The particular part of the image that received the strongest reaction was the cluster of swarming "snakes" atop the Well. I considered that this natural reaction to the snake image might reflect a normal aversion to shadow.

One question emerged: It was unclear whether the snakes were coming out of the well, through the cross-hatched opening at the top, or going into it.

Images of vessels (like the Well) frequently symbolize the Self. Curiously, my own Self had a crack in it, apparent in both the song lyrics and in this clay rendering. (See the lower left part of the image in Figure 1.) The crack first suggested to me a possible injury, but upon further reflection I could see that it was also an opening-perhaps even a passageway through which the snakes had been freed.

The art led me to appreciate the complexity of images and to see possibilities in imperfections. In my work as a therapist, I have tried to discipline myself to view symptoms, pathologies, and other therapeutic challenges as an artist does-not framing cracks such as these as "problems needing fixing" but rather appreciating their soul-making properties. Hillman has been an outspoken proponent of such an attitude. In a passage where he reflects upon "reading our lives backwards," he suggested, "Suppose we look at...kids who are odd or stuttering or afraid, and instead of seeing these as develop- 


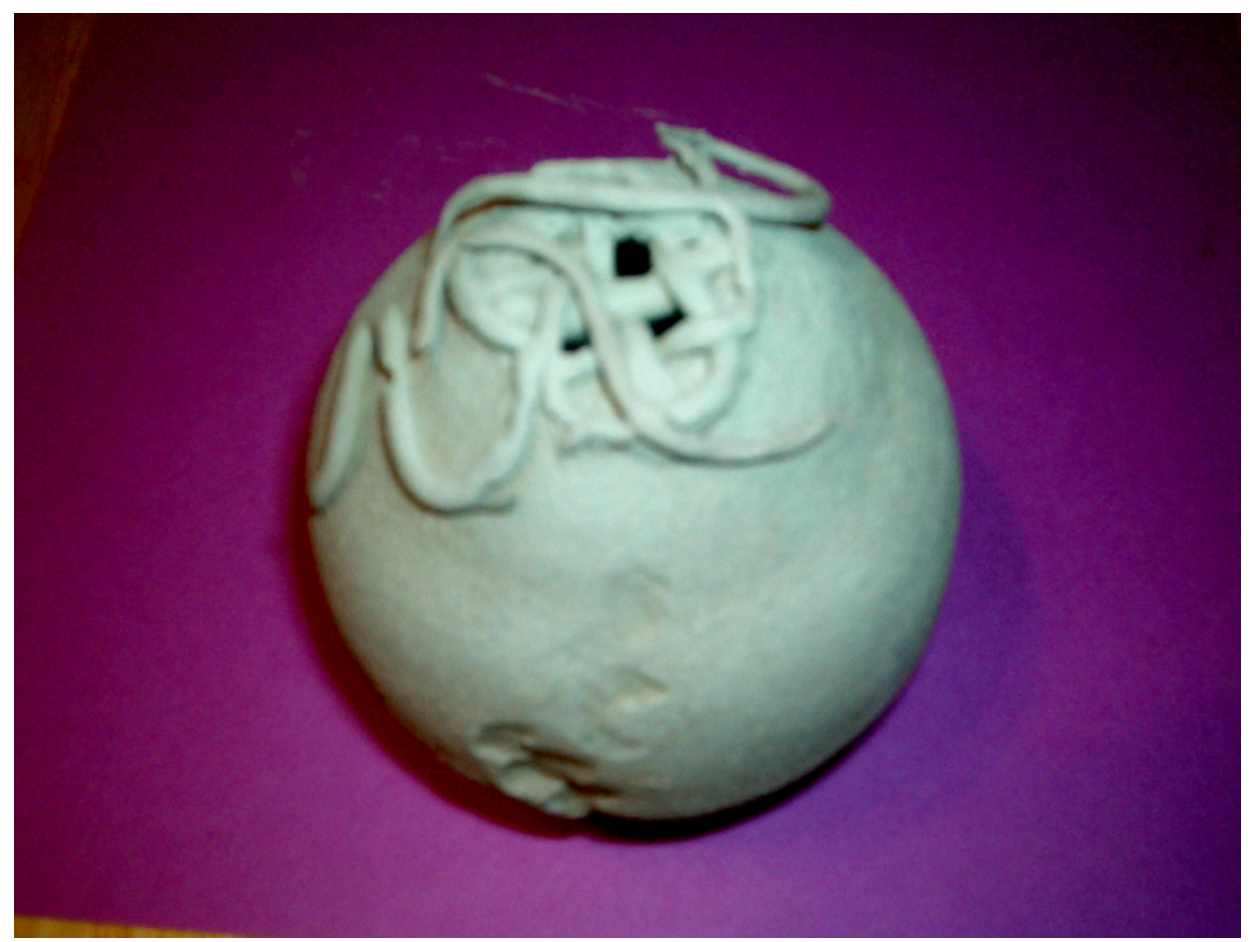

Figure 1

First rendering of the Well in fired clay, unglazed

mental problems we see them as having some great thing inside them, some destiny that they are not yet able to handle. It is bigger than they are and their psyche knows that" (1992, pp. 18-19). The crack was an intriguing part of the vessel image for me.

The vessel, Well or "Self" image reappeared as I proceeded through a series of artistic explorations. Although my initial understandings about the Well as Self and the snakes as human shadow both made great sense to me, for now I simply let the images incubate further and waited for them to reveal more about their nature and meaning in their own ways and in their own time.

A month or two after my first well-making experience, the art-based research group convened for another session, this time with bread dough. I had the idea to make a bread bowl, took a large mixing bowl and formed the dough over it, then decorated with other colors of bread and smatterings of parsley.

Directly across from me the potter in our group worked with her dough. She, too, had taken a bowl-a small cereal bowl-and was weaving the dough in a crisscrossing, lattice design. I watched her take small balls of dough and stuff these into exposed openings; I felt a tug of distress at this gesture but did not really understand why. We let the bread rise, baked it, and had our lunch.

Afterwards, as always, we brought out our creations to reflect upon them and to offer each other feedback. I made the observation that once again, snakes had appeared on my creation. I wondered if this could be the second in my Well series. Any doubts of this were allayed when, without speaking, the potter reached out, turned my piece over and placed her piece over mine-a perfect fit! (See Figure 2c , below.)

In this collaborative rendering, the crisscross opening of the well has spread, and it is now clear that the snakes have in fact traveled out from within the vessel, rather than the other way around. (I also understood why those hole-plugging gestures had been so disturbing to me, as the potter's piece resonated so closely with mine.)

Songs continued to arrive unbidden, and during this particular period of time the song There It Is arrived, a song that explored that indescribable feeling that for me often precedes the emergence of a song. This song emerged differently from the others; this time, as an experiment, I attempt to tease the song out instead of just waiting for it. The lyrics emerged as follows: 

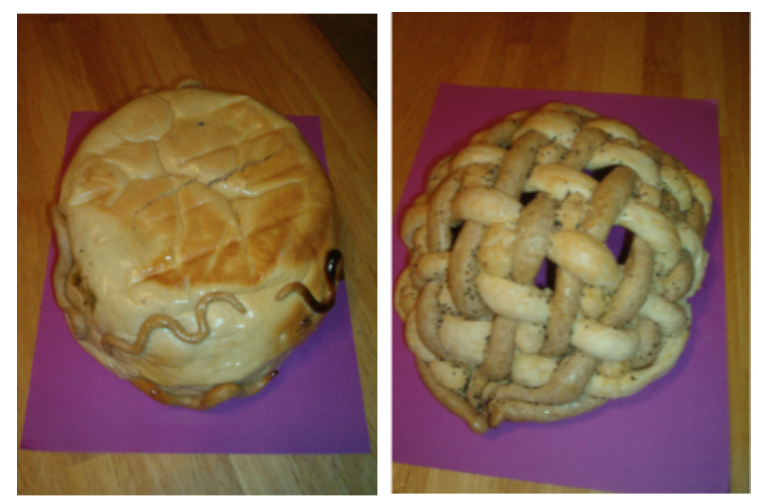

Figure $2 a$ and $2 b$

Second rendering of the Well in bread dough, next to a co-researcher's bread dough piece

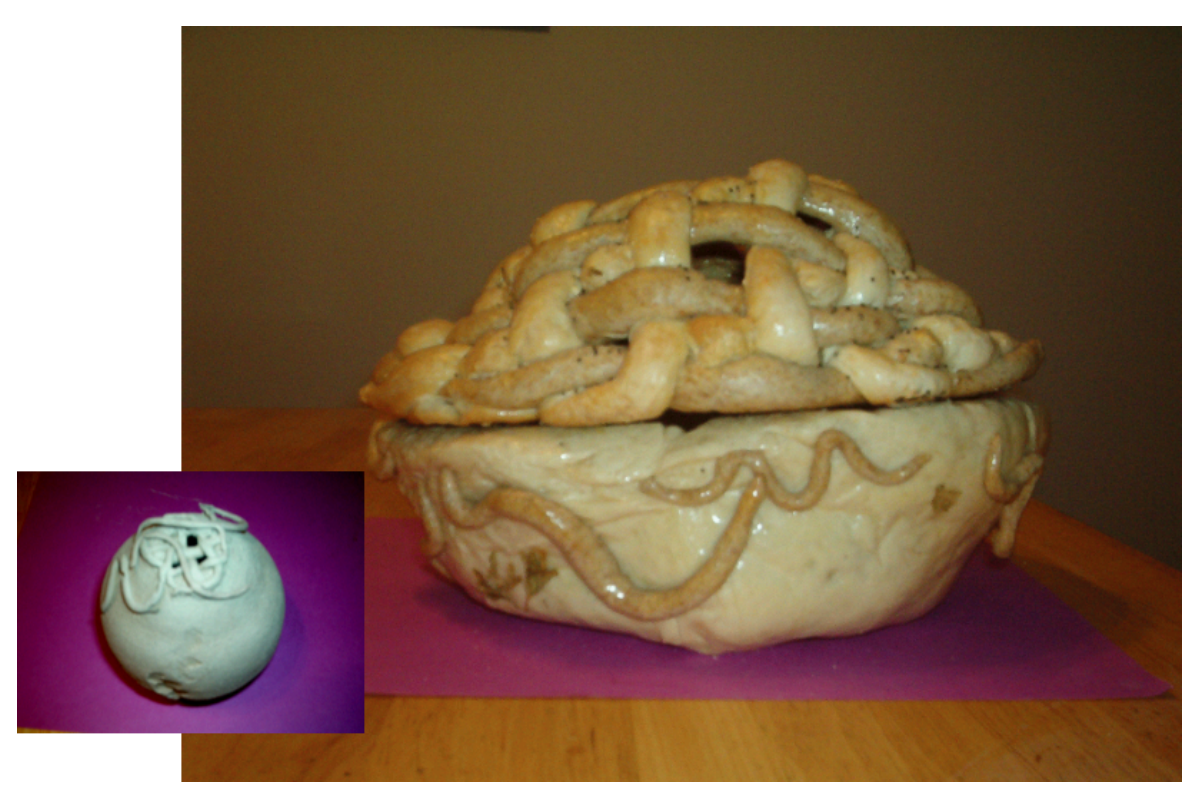

Figure 2c

"And the two became one."

\section{There It Is}

There it is, on the tip of my tongue.

I can feel it. I can't hear it yet.

But I know it's gonna come. I know it's gonna come.

[Repeat with key change]

And it's almost here. It's sitting in my heart,

Waiting for the words, waiting for the sounds to start...

There it is, in the palm of your hand.

I can see it, kiss it tenderly. Hold it close against my cheek.

God, if only it could speak.

And it's almost here. It's singing in my heart.

Waiting for the words, waiting for the sounds to start; start pouring out...

Ah-ah-ah-ah-ah-ah-ah-ah-ah, Ah-ah-ah-ah-ah, Ah-Ah, Mm-Hmmm.

There it goes, just as fast as it came. So surprising. Mysterious.

No, it's never quite the same.

I call "There It Is" my song of tacit knowing. On the day this song arrived, the feeling preceding its emergence was clear-but nonverbal, and therefore impossible to artic- 


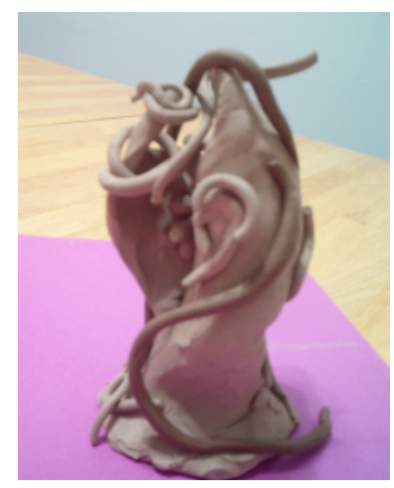

Figure 3

The Well opening, in unfired clay

ulate. In an effort to force it into an articulated form, I took up my guitar and began playing, hoping I would lure lyrics forth.

The lyrics that came first did not exactly feel right; rather, they seemed themselves to be speaking about being in pursuit of the thing embodied in the tacit knowing. When the "Ah-ah-ah..." interlude erupted, I felt an "Aha!" response. This was finally it, I thought. But soon afterwards, the song finished, and I began to question if in fact the entire song was not "it."

Once again I thought about the snakes, my shadow, and I began to wonder about the repulsion towards the snakes that two of my companion artists had brought to the table. I remembered that one woman who had found the snakes difficult to look at had also found a particular song of mine extremely unsettling (The One, Fall 2000). She shared that this song, laden with pothos (longing for impossible love), had hit "too close to home."

It was not difficult to understand why people would find shadow material unpleasant to encounter-especially their own. After all, that phenomenon of finding shadow repulsive and impossible to bear is precisely why people repress and project it! Whenever I review literature on the subject, I generally find theorists and practitioners commenting on the shadow material of other people, but rarely do they dare to examine and expose their own. Why, then, during this period of study did I seem to approach the task with veritable zeal? It did not make sense.

In time, I discovered the answer to my question. I found that shadow material exists in layers, and the first layers I reached in my heuristic study-my capacity for emotional coldness, for example-as unpleasant as such shortcomings might have been to look at, really functioned as distractions from the even more difficult shadow material that awaited me-my golden shadow. Indeed, I had buried my greatest gifts and talents-not the least of which were the songs themselves-more deeply than any other personal shadow material I encountered. Further, I was terrified to dig up that golden shadow, terrified too of the responsibility of fully owning it. But the art and song images lured me ever nearer to it with what I would discover to be the relatively benign snakes at the surface. Carefully tucked in the furthest depths of the moist, dark Well, I would discover "Pink Gold."

I will explain the Pink Gold a little later. For now, see how the snakes were set free as the series progressed! In Figure 3 , below, completed a few months after those initial clay pieces, the Well opens and releases snakes in hordes. There are more than I ever suspected, no longer trapped inside the well, but having emerged through a gradually widening crack. Completing the piece below generated strong feelings of liberation, embodied and expressed in the song Break Out.

During the research period, prominent images like snakes entered into dreams as well, and even life experiences. For brevity, only one especially strong dream will be recounted here: 


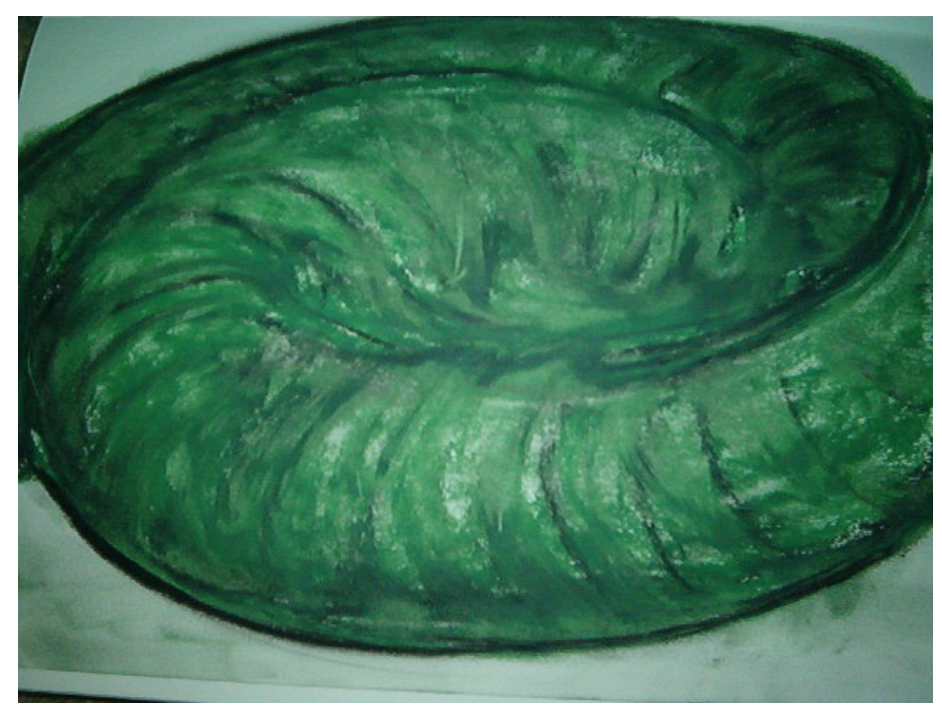

Figure 4

Image from "Snake Grown Large" dream in oil pastels on paper

I was in the kitchen, and I wanted something from a high cupboard I rarely used and could not reach, so I asked my husband to open it for me. When he did, an enormous green snake, the size of a boa constrictor you might find in a jungle, fell to the floor. It was around 10 feet long. He immediately wanted to kill the thing, but I felt protective of it.

Suddenly, I remembered I had put that snake in the cupboard myself many years earlier when it was very small. I felt awful that I had forgotten the poor snake and left it trapped in that ever-more-confining cupboard for so long. Now that it was free, I wasn't at all sure how I'd deal with it; because of its size, I feared that others might want to harm it.

I felt inspired to create an oil pastel of the snake in this dream ( Figure 4 , below). Note that the snake is so overwhelmingly large that it extends even beyond the confines of the paper on which it appears. This snake seems linked to the songs I had shut away for so long-in truth, since the time when the song When I Was a Child appeared during my early adulthood. In a sense, I really had put a tiny green snake, in its infancy, into a high cupboard and had "forgotten" it until many years later. But rather than go away, it grew! And this is precisely what happens with shadow when one tries to stuff it away somewhere-it becomes bigger, and potentially far more dangerous than it might otherwise be.

In 1991 Robert Johnson wrote, "To draw the skeletons out of the closet is relatively easy, but to own the gold in the shadow is terrifying" (p. 8). Snakes were not the only contents of the Well. A soft pinkness also appeared within the teardrop-shaped vessels that came into my doodles, drawings and paintings; these were also Well renderings, in a sense-"Self" images. The soft pinkness eventually evolved into, or led me to, a thing that came to be named Pink Gold, representing my golden shadow.

As far back as I can remember, many of my idle moments were taken up with doodling. I found it meditative, but I never gave the doodles I produced much thought until I began to study them in the context of art therapy-first in a major paper on using doodling as a projective technique in psychology (Fox, 1980). For this project, I collected a number of my doodles and examined them to see what I could see. Many of these images also made it into my master's thesis, an art-based study in 1988 entitled "Toward a Psychology of Recurring Imagery."

In 2002 the painting "Pink Gold" emerged ( Figure 5 , below). The pinkness appears to be well-guarded, held in warm blackness inside a carefully constructed border, happily showered with sparkling bits of gold all around.

Near the end of my doctoral study, as I began sifting through data and trying to make sense of it, I went for several weeks without any songs coming to me. I thought that the series might be over. But I was wrong. At the proverbial "eleventh hour," the re- 


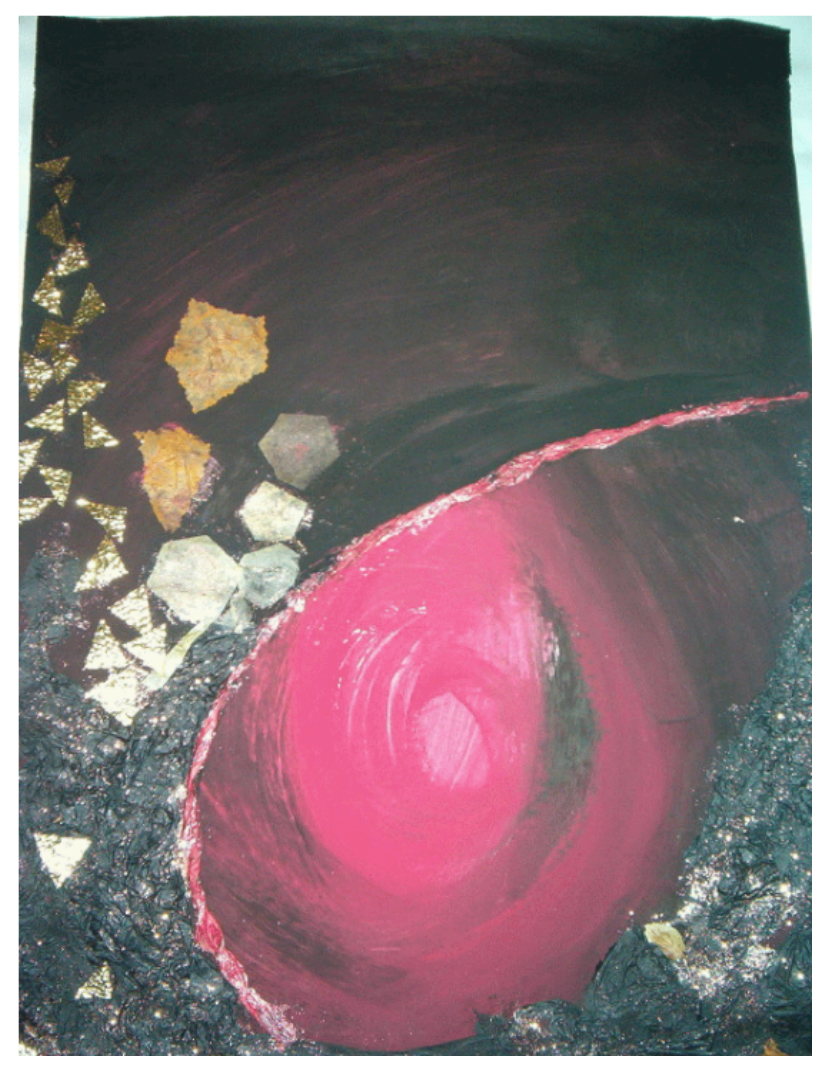

Figure 5

"Pink Gold" in tempera paints, tissue paper and mixed media

frain to Be Careful What You Wish For came to me one night, with the verses arriving the following day. This new song-lyrically, melodically, and harmonically-marked a synthesis and retrospective of the personal work I had done with my songs over a course of 25-years, as indicated below:

\section{Be Careful What You Wish For}

I put it in my pocket, ${ }^{2}$ so many years ago.

A tiny little locket. ${ }^{3}$ My secret Cameo.

And how I loved it, that most precious thing.

But how it yearned to sing. ${ }^{4}$

I hid it from my Daddy ${ }^{5}$-from everyone around.

Let go a moment, broke my heart, ${ }^{6}$ and I pushed it deeper down;

Oh, how I loved it, that most precious thing.

But oh, how it yearned to sing.

\section{Refrain:}

Be careful what you wish for. Be careful what you pray.

Beware the mysterious ways of the Universe.

Beware of what you're feeling and knowing deep inside. ${ }^{7}$

Prepare for a Helluva ride. ${ }^{8}$ Be careful what you wish for.

Dear God, I am so frightened. I know it's almost time.

My pocket's worn, and much too small, and this thing, it isn't mine.

And how I love it, that most precious thing. And how it yearns to sing.

[Repeat Refrain]

One of the ways in which this song seemed to be a synthesis of all that had come before was the way in which fragments of lyrics and images from earlier songs entered into this one. I indicate these fragments with hyperlinks in the footnotes referencing those lyrics. In addition to these lyrical links, the song possesses chord progressions similar 
to those in the introduction to Winter's Coming as well as musical phrasing found in the song If I Could Ride a Butterfly.

As the heuristic data presented here illustrates, the songs led the way into this study of human shadow, with other modalities like painting, dreams, and also authentic movement (for example, times when I might practice embodying a compelling image, not described in this abbreviated passage) assisting the process by interacting with and enriching the song imagery.

At times, the songs appeared to function somewhat like premonitions. They "knew" things long before "I" (Ego) knew them, and often these awarenesses were apparent to my co-researchers before they were apparent to me. Of course, this is the way of shadow. It is far easier to see the "speck in someone else's eye than the log in my own."

And yet, without mincing any words (or imagery), it seemed that the songs did present their wisdom to me, albeit in a remarkably gentle fashion. If someone had attempted to impart directly what the songs told in their gentler, metaphoric way, I would have probably blocked my ears and averted my gaze. As it was, the songs were compelling. I could not help but listen to them, over and over, and in time I heard what I was ready to hear-new things at different times. None of it was particularly easy. I had to face my shadow and the complex array of feelings that were aroused. Through old and new songs, I examined painful aspects of my closest personal relationships. Concomitantly, steeped in this process, previously forgotten songs reemerged and functioned very much like forgotten memories. Many questions remain unanswered, new mysteries unfolded, and in time I understood how the songs introduced me to shadow material that resonated with my own understanding of myself and my lived experience.

The attention I paid to the images who befriended me paid dividends in that I noticed transformations in their content and character. Old themes of confusion and uncertainty have gradually faded. I have noticed my Animus evolving, growing stronger and more mature, and this has been revealed not only in my imaginal life but in my "actual" life as well. I have been able to "draw my sword" and fight important battles with a confidence and skill I had not felt called to muster before. The change has indeed made me more whole. Encountering and embracing shadow material of course also served me well by helping to make me more self-aware and therefore more able to offer a container better equipped for the broad array of therapeutic material my clients brought to sessions with me.

\section{Discussion}

...Songwriting is much more than a mere craft. It's a conscious attempt to connect with the unconscious; a reaching beyond ordinary perceptions to grasp images that resonate like dreams, and melodies that haunt and spur the heart. (Zollo, 1997, p. xii).

Songs, art and dreams often contain introductions to shadow, messages and lessons, and the most profound ones may arrive unbidden. Opening to the gifts of the imaginal realm requires discipline and courage, but not without reward. Human shadow material present in art and songs in particular offer a rich reservoir for Self-discovery.

That said, my primary purpose in this study was to achieve a deeper understanding of the creative process of songwriting and to explore therapeutic implications of the learning gained through this research. My heuristic explorations with song and art, along with the knowledge I gained by interviewing other songwriters (not included in this summary), all contributed to this learning. As I examined the essential themes that emerged from this learning, it became clear that this was overall a theory-building endeavor, producing a model to guide the work of the artist-therapist. I will take the opportunity in this discussion to elaborate upon this model.

The reader may observe that in the course of this research I endeavored to approach and relate to the heuristic and interview data primarily through an artist's lens. At first blush, this may not seem like a very "psychological" approach. But if we contem- 
plate the matter carefully we will remember that psychology is at its root "the study of Psyche," and that Psyche and all its contents originate not in our "actual" world, but rather in the transcendental or imaginal realm-the same realm from which dreams, art, and music emerge.

To understand Psyche fully, and to approach psychological healing both individually and collectively, we must dare to enter consciously into that imaginal realm, learn its language, and engage creative processes that promote the healing of psychological wounds. A willingness to "go deep" is especially important for shadow work, and the arts are particularly well suited to this endeavor. Stephen Diamond wrote:

By bravely voicing our inner "demons"-symbolizing those tendencies in us that we most fear, flee from, and hence are obsessed or haunted by-we transmute them into helpful allies, in the form of newly liberated, life-giving psychic energy, for use in constructive activity. During this process, we come to discover the paradox that many artists perceive: That which we had previously run from and rejected turns out to be the redemptive source of vitality, creativity and authentic spirituality. (Zweig \& Abrams, 1991, pp. 186-187)

The precise way of working with images described here, at its core, aims to enable encounters with human shadow material. This practice aids individuals, groups, and humanity as a whole by heightening awareness of unconscious material, which when brought to awareness in a nonjudgmental manner helps people achieve wholeness. Owning the parts of oneself that may have previously been repressed or projected onto others serves as an antidote to fear and aggression and encourages human compassion. Further, when art that originates of its own accord is honored and shared in an intimate therapeutic context, or even in a more public performance or on a global scale, resonance is made possible, and this resonance can usher heightened awareness and change among all who are open to such influence. Publication of art-based research can itself extend the reach of such artistic products for the betterment of humanity.

Von Franz (1995) sees shadow work as something of a responsibility, especially with regard to repressed creativity, stating:

...having the possibility of becoming conscious and not taking it is about the worst thing possible [and] one of the most wicked, destructive forces, psychologically speaking, is unused creative power... If someone has a creative gift and out of laziness, or for some other reason, doesn't use it, that psychic energy turns into sheer poison. (p. 214)

So how does one think and work like an artist, and how does this approach differ from other approaches to psychotherapy? Perhaps it is useful to examine some common assumptions held by traditional psychotherapists and to contrast these with my own root assumptions as an artist-therapist.

Let me briefly address the origin of these ideas. While Jung afforded me access to a conceptual understanding of the human shadow, James Hillman's writings gave practical support to how I might go about engaging the shadow's realm, the imaginal realm. For some time, I have followed several principles that came naturally to me as an artist and were affirmed by Hillman, including having a respect for the autonomy of images and recognizing the important role of images in the healing of Psyche. Hillman himself does not profess to be an artist, however, he was well acquainted with the imaginal realm and for many years engaged images, primarily as a psychologist working with dream material.

A description of my root assumptions as an artist-therapist, thus supported in Hillman's and Jung's theories, follows.

\section{“Being" versus Development}

Modern psychology promotes the notion that people "develop." There is an assumption that after a child is born, if all goes well, he moves through developmental milestones in a kind of linear order until he reaches the end of life and dies. Picasso once said, "I don't develop. I am." This statement illustrates the way of the artist-not to develop, but to be, to reach for ever-deepening understandings about the richness of images- to 
cycle repeatedly through the same recurring patterns and "dysfunctions," appreciating the complexity of life a little better each time around, with each artistic rendering. In this model, the emphasis is not on creating fundamental change, per se, but rather on creating ever richer and perhaps more adaptive relationships with people, images and situations-even with our symptoms.

\section{Analyzing Unconscious Material}

Here is another popular traditional notion, at least among those with a psychodynamic approach: A psychotherapist's job is to analyze the unconscious.

Artists have no interest in applying psychological jargon to art when that language is not based in the art itself. Fortunately, psychological healing is possible without that kind of analysis. Children already know how to do it, and the rest of us would do well to remember how. In play therapy and in expressive arts therapy with nonverbal adults, I may serve as an important witness to clients' processes, but I never worry about their ability to verbally articulate the therapeutic process. It is not necessary, since healing happens on a purely metaphorical level.

Of course, acknowledging the ways in which art can heal without the application of various forms of psychological analysis is not a complete response to this problem. If one does not analyze the art in treatment, then what does one do with it?

Hillman (1989), who primarily engages images through dreams, suggested that we "befriend" the images we encounter. He wrote:

The classical Jungian attitude toward the dream is expressed very well by a term I would borrow from existential analysis...This term is to befriend the dream. To participate in it. To enter into its imagery and mood, to want to know more about it, to understand, play with, live with, carry, and become familiar with-as one would do with a friend. (p. 241)

This befriending supports an erotic (i.e., sensual, not sexual), "imaginal love" relationship, which is a two-way street. From experience, I know that therapy conducted within a loving container can hardly go wrong. Hillman also (1989) said:

...dreams mean well for us, back us up and urge us on, understand us more deeply than we understand ourselves, expand our sensuousness and spirit, continually make up new things to give us-and this feeling of being loved by the images permeates the analytical relationship (p. 282).

It is clear in examining the ways of the imaginal realm that all its contents-including human shadow content-all these images love us. It might seem at times that their intention is to torment us, since the essence of shadow, by definition, is so difficult to bear. But in fact, shadow's intent-like the Big, Bad Wolf's intent towards the Three Little Pigs-is to teach and to care for us (Bates, 1991).

Taking the story of the Three Little Pigs as an example, as Bates has done so eloquently (1991), we observe that in the end the Wolf's commitment to teaching the pigs led him to sacrifice his own life in order to be eaten by the third pig, who ultimately was the only pig able to overcome naiveté and muster adequate courage to meet his teacher's demands. The pig's ultimate reward was wisdom and advancement to higher levels of consciousness.

Another approach that goes with befriending images is the practice of personifying them, another one of Hillman's terms. Hillman (1989) said:

Personifying not only aids in discrimination; it also offers another avenue of loving, of imagining things in a personal form so that we can find access to them with our hearts....personified words tend to become cherished and sacred, affecting the reason of the heart. (p. 46)

To enhance this process, I typically refer to the primary images with which I am working with capitalized letters, a practice Jung used when referring to archetypes. I also believe that this practice of "naming" is another example of the artist's way with im- 
ages. It reminds me of my habit of naming my dreams as they emerge. It is a natural, intuitive and imaginative response (not a carefully thought-out, analytical one) that helps to reveal the essence of a thing, functioning precisely the same way as the naming of a work of art, offering another way for images to reveal themselves.

\section{Seeing Creative Opportunities in "Flaws"}

I challenge the notion that psychological "disturbances" must be identified and ameliorated. An artist is neither blind to flaws nor a stranger to suffering. But artists see possibilities and creative opportunities in imperfections. The goal is not to eliminate them, but rather to explore and perhaps to make something out of them.

An artist views a knot in a piece of wood not as a flaw, but as a creative opportunity-perhaps the most interesting and evocative aspect of a given piece of art. A poet takes an image of ugliness and shows us the beauty in it, permitting it to reveal itself in all its complexity.

Hillman described symptoms as having "soul-making" properties. He said, "Our symptoms are actually the irrepressible imagination breaking through our adapted mediocrity ... In your pathology is your salvation" (Hillman \& Moore 1994, p. 154). He went so far as to say, "in my symptoms is the soul's deepest desire" (p. 158) and "We owe our symptoms an immense debt. The soul can exist without its therapists, but not without its afflictions" (1989, p. 144). Images revealed to us through our symptoms, as in our dreams and art, offer paths to Self-discovery and healing.

\section{The Myth of Control}

Many believe that the aim of psychotherapy is to bring one's life into better control. An artist's aim is not to control, but to simply create a space within which images and therapeutic material can appear, and then to engage and interact with that material. The goal here may not be control so much as a kind of grace and acceptance of things as they are and a willingness to cooperate with our realities, to deepen our understanding of them, and to imagine or re-imagine possibilities for engaging them. Life becomes more a matter of adventure, discovery, and mutual love with images than of hardship, mastery or tolerance.

\section{What Images "Mean"}

Psychologists and psychoanalysts commonly accept that an image's only meaning comes from the meaning people project upon it. But images have lives of their own. Most artists' awareness of images' autonomy and intentionality is apparent in their choosing not to approach art as a volitional act entirely guided by Ego. A painting "tells me" when it is finished, for example. A sculptor chips away at a block of wood until the sculpture reveals itself to him. Moreover, the meaning of images is never finite. Images are infinitely complex and rich with possibilities. They continue to reveal themselves in new ways the more we ponder them.

\section{The Therapeutic Alliance and the "Third"}

Most believe that psychological healing emerges through the relationship between therapist and client. I believe that this is only partly true, that psychological healing depends upon the presence of the "Third" (Knill et al., 1995, /2005, p. 124). As an artist-therapist, I work not in service of the client per se, but rather in service of this Third, a presence rooted in the imaginal realm.

The Third is that which becomes present when two or more are gathered. It may manifest in art pieces that a client or client and therapist produce, but it does not necessarily require that there be an artistic creation.

Mary Priestly (1994) referred to the phenomenon of the Third in her book on analytical music therapy. She recollects a moving experience of the Third while engaging in what she calls a "Receptive Creative Experience (RCE)": 
This kind of music seems to be experienced in an extra dimension ...There can be a sense of the environment closing in with heightened tension...or a reaching up to a psychic area of light and freedom into which the sounds leap with ecstatic excitement and the two players become not one but three...the third being the containing matrix of the music's wholeness. It is as if the music were already composed, and with each note one is guessing correctly what must follow. (p. 321)

My personal experience, reading and interviews with other songwriters reveals some dispute among songwriters over what to call or how to name the source of the creative, songwriting impulse. In the interviews I conducted, songs were attributed to: life experience, God, spirit, and shadow. One may conceptualize any one of these potential sources as a kind of "Third." That is, whether Source is imagined as coming from inner or outer spaces, it always carries with it a sense of otherness, and accessing it seems to depend upon an open and even submissive posture and an ability to cultivate intuition as opposed to intellect. Unable to direct or "think" their ways into their best songwriting, songwriters need instead to exercise intuitive powers, open to the imaginal realm, and submit to the Muses. (Not surprisingly, perhaps, artists tend to score high on the Intuitive Scale in the Myers-Briggs Personality Type Indicator (Hartzell, 1998).

Singer/Songwriter Ricki Lee Jones described an intuitive process that happens only occasionally for her, a phenomenon she called "Second Sight." Second Sight, she explains, sees something happening in your life and needs to write about it, unbeknownst to you, and when you're done you learn something from what you've written. "Those are songs you kind of write with your eyes closed" (Zollo, 1997, p. 479).

All the above assumptions form a basis for a model of psychological thinking grounded in the arts. The song series, art-based research process and creative musical synthesis elaborated above demonstrates how to bring an artist's eye to research. This approach also applies to the psychotherapeutic process. The following section offers specific applications useful when cultivating the benefits of songwriting in work with clients.

\section{How to Access the "Giver of Song"}

Moustakas' six stages of heuristic inquiry detailed above provide a useful structure for describing the creative process. My own experience with these stages mirrored the experiences of other songwriters interviewed for the dissertation upon which this article is based (Fox, 2005). A few common themes identified suggest particular guidelines that may be useful in working with clients:

1. Make time. Time for incubation and reflection is a key factor in songwriting. But it does not appear to be essential that songwriters have unlimited time available to them. Imposed deadlines may offer creative limitations or boundaries that function somewhat like the limitations presented by the size of a painter's canvas. Moreover, the time required for any given song to emerge can vary considerably. Some songs are written a little bit at a time over a long course. A few arrive in a flash—although these quickly written songs may have incubated for a long time before finally emerging.

2. Establish and honor "right conditions." The "right conditions" for songwriting vary among songwriters. Most require a quiet and relaxed setting in which to concentrate. Some write better in the morning, some in the evening. Some preferred indoors, some outdoors. Some prefer a structured routine and block out particular hours every day for writing, although they admit there is no guarantee that songs will emerge, only that if and when a song does come, they will be ready to receive it. Others prefer more spontaneity-continuing about their business until they feel a song coming on.

Nearly all songwriters fare better when they are not under specific pressures to write, not so much with respect to the time allotted but rather with respect to song content. Getting a song written in two weeks' time, for example, is not such a tall order as being commanded to write a song on a particular subject, in a par- 
ticular style-for example, "just like the last one you wrote, the one with all that commercial appeal." In this respect more than any other, songs appear to have minds of their own.

3. Set aside "Ego" and surrender to the song. The initial stages of songwriting seem to require a setting aside of Ego or intellect so that one can freely receive whatever the song is bringing forth. It is not as if one actually disengages one's brain; rather, one initially adopts a receptive rather than a controlling attitude-an attitude of openness, honesty and surrender.

At some point after the song's initial emergence, the intellect can be brought to bear more actively in order to aid in shaping, notating or recording and fully realizing the song, though it seems important to maintain an intuitive or aesthetic connection with the song's own intent. At this stage, it becomes a kind of creative collaboration.

The process of opening to and surrendering to the songs has certainly aided in the human shadow studies described here. It seems that the more "otherly" the source, the deeper and truer the contents. This acute experience of otherness assures that Ego, which can have a tendency to "stretch the truth," or at least to present it in the most egosyntonic manner possible, is not terribly involved with the songs' initial emergence.

4. Share the creative products. Woody Guthrie, a well-known American folk singer, once said that songwriting is like fishing. "You put your line in and hope you catch something" (Zollo, 1997, p. 71). I have found that my own remarkable moments come when the fish aggressively pursue me, when they wake me up in the middle of the night or pull me over to the side of the road and throw me a line. Nearly all my songs emerge this way.

This sense of "otherness" noted time and again in this research reinforces the essential autonomy of songs and images produced by humans. As autonomous entities, they possess a life of their own and belong not only to the most immediate recipient (e.g., the songwriter), but also, in a much larger sense, to the world. From a therapeutic standpoint, the process of sharing one's creations allows for the affirming experience of resonance, shared insight and meaning, and emotional reciprocity.

As noted in the lyrics of the last song of this series, the "creative synthesis" (Be Careful What You Wish For): "This thing, it isn't mine."

\section{Future Research}

After a powerful encounter with music therapist Margaret Tilly near the end of his life (see Hitchcock, 1987), Jung appealed for more study and research in the area of music and psychotherapy, noting that he would certainly move towards music to advance his own theories had he more years left in his life. Art-based approaches may be just the ticket to pick up where Jung left off and see how the field of analytical and imaginal psychology can be advanced through further theory development and research that incorporates what other forms of research have informed us about music and the human psyche.

A particularly compelling area of research inspired by this study concerns the phenomenon of resonance, how human engagement and collaboration affects the creative process, and how sharing songs affects the experiences of songwriters and listeners alike. Such inquiry would enter the realm of transpersonal psychology and take the work of Carl Jung and James Hillman beyond individuation and into a deeper exploration of collective consciousness and the imaginal realm-the next frontier.

Beyond these calls for further research, arts-based practitioners of all sorts, and those who educate them, may benefit from remembering to respect the compelling autonomy and intent of the images with which we work day by day, for herein lies the real magic in the work we do. If we remember how to behave as artists do, we will undoubtedly benefit from setting aside Ego so that other images may capture our at- 
tention and literally lead us to our own healing. This can be no better illustrated than in the smooth ability of the imaginal realm to introduce us to otherwise difficult-toface shadow material and to help us integrate it into our psyches.

\section{Notes}

1. One of the aspects of shadow, which stood out to me in this song is its sense of humor. John Sanford points out that people who lack a sense of humor probably have very repressed shadows (Zweig and Abrams, 1991, p. xviii). Sanford notes, "It's usually the shadow who laughs at jokes."

2. "I put it in my pocket" is also a lyric from When I Was a Child.

3. This lyric pulled from a song created during my doctoral study, The Locket.

4. This yearning to sing is also depicted in the song of tacit knowing, There It Is.

5. The song Daddy appeared around the same time as When I Was a Child.

6. The "breaking of my heart" references the story of when my first love (Moayid) "left me in disgrace," from my song, The One

7. All the songs in their own ways reflect a "knowing deep inside," but some referenced this more directly than others. They included Break Out, The Path, There It Is and Winter's Coming.

8. The cursing language here is reminiscent of The Well.

\section{References}

Barone, T., \& Eisner, E. (2012). Arts based research. Los Angeles, CA: Sage Publications.

Bates, C. (1991). Pigs eat wolves: Going into partnership with your dark side. Paul, MN: YES International Publishers.

Fox, H. (1980). Doodling as a projective technique. Northfield, Minnesota: St. Olaf College. Unpublished independent research project.

Fox, H. (1988). Toward a psychology of recurring imagery. Cambridge, Massachusetts: Lesley College Graduate School. Unpublished master's thesis.

Fox, H. (2005). Songwriting and self-discovery: A heuristic study grounded in the arts and supported by the theories of Carl Jung and James Hillman. Cincinnati, Ohio: The Union Institute and University. Unpublished doctoral dissertation.

Diamond, S. (1991). Redeeming our devils and demons. In C. Zweig \& J. Abrams (Eds.), Meeting the shadow: The hidden power of the dark side of human nature (pp. 186-187). Los Angeles, CA: Jeremy P. Tarcher, Inc.

Gendlin, E. (1982). Focusing (2nd ed.). New York, NY: Bantam Books.

Hartzell, E. (1998). Visual creativity through the prism of psychological type. Santa Barbara, California: Pacifica Graduate Institute. Unpublished doctoral dissertation.

Hillman, J. (1989). A blue fire: Selected writings by James Hillman. New York, NY: Harper \& Row.

Hillman, J. (1983). Archetypal psychology: A brief account. Dallas, TX: Spring Publications.

Hillman, J. (1977). Re-visioning psychology. New York, NY: Harper \& Row.

Hillman, J., \& Moore, T. (1990). A blue fire: The essential James Hillman. London: Routledge.

Hitchcock, D. (1987). The influence of Jung's psychology on the therapeutic use of music,. British Journal of Music Therapy, 1, 17-21, https://doi.org/10.1177/135945758700100204.

Johnson, R. (2009). Owning your own shadow. San Francisco, CA: HarperCollins.

Kapitan, L. (2017). Introduction to art therapy research (2nd ed.). New York, NY: Routledge.

Knill, P., Barba, H., \& Fuchs, M. (1995/2005). Minstrels of soul: Intermodal expressive therapy. Toronto, Canada: Palmerston Press/EGS Press.

Leavy, P. (2018). Handbook of arts-based research. New York, NY: Guilford Press.

McNiff, S. (1998). Art-based research. Philadelphia, PA: Jessica Kingsley Publishers. 
Moustakas, C. (1990). Heuristic research: Design, methodology and applications. Newbury Park, California: Sage Publications. https://doi.org/10.4135/9781412995641.

Moustakas, C. (1994). Phenomenological research methods. Thousand Oaks, CA: Sage Publications. https://doi.org/10.4135/9781412995658.

Priestly, M. (1994). Essays on analytical music therapy. Phoenixville, PA: Barcelona Publishers. Sanford, J. (1991). Preface. In C. Zweig \& J. Abrams (Eds.), Songwriters on songwriting. New York, NY: De Capo Press.

von Franz, M. (1995). Shadow and evil in fairy tales. Boston, MA: Shambhala.

Williams, A. Z. (September 9, 2016). Carroll gardens. $16^{\text {th }}$ Street Theater, Berwyn, IL 60402.

Zollo, P. (1997). Songwriters on songwriting. New York, NY: De Capo Press.

Zweig, C., \& Abrams, J. (Eds.). (1991). Meeting the shadow: The hidden power of the dark side of human nature. Los Angeles, CA: Jeremy P. Tarcher, Inc.

\section{Appendix}

\section{Index of Selected Original Songs by the Author}

Early Period (Songs retrieved from early adulthood)

- When I Was a Child (1980)

- Daddy (1980)

- Moayid (1981)

Late Period (Songs written during the doctoral study process)

- The One (2000)

- Break Out (2000)

- Winter's Coming (2000)

- The Well (2001)

- There It Is (2001)

- The Path (2002)

- If I Could Ride a Butterfly (2002)

- The Locket (2002)

- Be Careful What You Wish For (2004) 